\title{
ПРАВОВЫЕ МЕХАНИЗМЫ ГОСУДАРСТВЕННОСТИ: ДЕКОНСТРУКЦИЯ КОНЦЕПТОВ
}

\author{
(c) 2021 Красников Иван Сергеевич
}

аспирант, преподаватель кафедры теории государства и права им. Г.В. Мальцева

Юридического факультета им. М. М. Сперанского Института права и национальной безопасности Российская академия народного хозяйства и государственной службы при Президенте РФ, Россия, Москва

E-mail: krasnikov.iwan@yandex.ru

В статье предпринята попытка проследить политико-правовую традицию, из которой возникло представление о механизме государства. Автор критически раскрывает теоретические противоречия, которые были опосредованы работами юристов-классиков. Анализируется связь механизма государства как с основными параметрами измерения структуры публичного властвования, так и с ценностными коррелятами - эгалитаризмом, индивидуализмом и постдемократией.

Ключевые слова: правовые механизмы, государственность, эгалитаризм, индивидуализм, публичная власть.

В широком смысле юридические механизмы выражают принципы правового регулирования, нацеленные на описание моделей рассосредоточения элементов государственности. В странах с развитой правовой культурой такими единицами выступают институты публичной власти. В политико-правовых системах с доминированием потестарных институтов, напротив, будет отражаться лишь институциональная архитектура государственных органов.

Общим местом стали рассуждения о преобладании принципа разделения властей как универсального механизма. Видимо, источником подобных рассуждений стала идея веры в «прогресс свободы». Конструирование модели организации власти, которая бы мешала её сосредоточению - преломление центральной идеи нововременной политико-правовой философии. Подобный нарратив создал условия проникновения и закрепления в нормативно-правовых текстах этого принципа. Однако, правовые системы, которые базировались на принципе «единовластия», продемонстрировали герметичность к изменениям; нетрансформируемость.

Прежде чем отличить разделение властей реальную от номинальной*, следует сказать, что сам по себе принцип единовластия не является гомогенный. В связи с этим необходимо рассмотреть разные формы единовластия в политико-правовой современности. Автор нацелен обобщить понятия, которые нам остались от представителей теорий конституционного и административного права, и выявить их (не) актуальность применительно к существующим политическим общностям; прежде всего - к Евросоюзу.

Не смотря на проявление тенденций к глобализации, созданию общеевропейского пространства, внимание конституционалиста ЖанПоля Жакке привлекало (1) «формы правления, основанные на совмещении властей» [4 C.92]. Можно сказать, что французский исследователь вывел целое дерево форм неограниченной власти. Первое - это проявление «диктатуры исполнительной власти»: ситуация совмещения функций исполнительной власти и законодательной в одном лице. При этом способ возникновения этого «правомочия» может возникнут из двух состояний: (1.1) личная диктатура, которая возникла благодаря военному перевороту; (1.2) диктатура, которая использовала плебисцит как механизм легитимации (цезарийская / бонапартийская модель) [4 С.92]. По мнению Жакке, в XX веке цезарийская модель была замещена авторитарным режимом, для которого характерно узурпация властных механизмов и упадок права, но сохранение автономности человека на уровне его правоотношений в сфере экономи-

\footnotetext{
* Иначе говоря, декларированность. Некоторые авторы имея в виду это рассматривают принцип разделения властей как «идеологический концепт» (см.: Антонов М.В.Теория государства и права: учебник и практикум для академического бакалавриата. М., 2019.С. 140.)
} 
ческих и приватных взаимодействий [4 С.92-93]. Второе - это «правления собрания». По мысли конституционалиста, ситуация, когда власть законодательная захватывает полномочия власти исполнительной, начиная занимать доминирующее положение в обоих сферах. Жакке считал, что примером такой формы неограниченной власти являлся Верховный Совет в СССР в том смысле, в котором он выражал власть органов Коммунистической партии. В одном ряду с этим примеров, у автора соседствует объёмом властных полномочий в Швейцарии [4 С.94-95].

Подобная классификация открыта для критики по многим основаниям. Прежде всего, неясны критерии, по которым представляется возможным разделять власть на «исполнительную» и «законодательную» в тех системах, в которых отсутствует механизм ограничения власти. Поскольку роль исполнительной власти в подобных сверхцентрализованных («монократических») системах может исполнять так называемая «судебная» власть. Подобное разделение носит условных характер и выстраивается не по принципу конкурирующих функциональных задач, a - по разделению труда; суверен нуждается в тех, кто будет воплощать его волю в разных сегментах социальной действительности.

Кроме этого, подобная классификация имманентно содержит в себе подразумевание качественной разницы между одним лицом и группой лиц, на которых замыкается «вертикаль власти». Между тем, важным представляется, что есть сам институт главенства, а не то, как называется орган, который выполняет его функцию; в силу культурного разнообразия этот институт может называться по-разному: президент, султан, монарх и проч. Важно с этой точки зрения - та функция, которая выполняется социальным институтом.

Другой крупный представитель доктрины, выражающей сущность правовых механизмов, был Ориу Морис [8]. Несмотря на то, что предметом исследования данного автора был принцип разделения властей, он пристально рассматривает вопрос кризисов, которые свойственны для зрелого государства в период его децентрализации; по мнению Мориса, децентрализация - неизбежная фаза любой государственности, которая преследует цель установления гражданской и политической свободы [8 С.540]. Но сам процесс распада властных полномочий - откалывание и их отчуждение в образовавшиеся новые социальные центры - может спровоцировать обратных эффект: сосредоточения власти в одних руках. Для описания этого явления автор создаёт классификацию возможных случаев, т.е. конструирует грибницу диктатуры: генеалогию моделей узурпации власти. Точнее автор фиксирует не просто наличие разных направлений деятельности государственных структур, а - формирование двух «систематических доктрин» [8 C.540].

Прежде чем критически рассмотреть эти две концепции, необходимо прояснить ценностные взгляды автора (иначе говоря, выявить аксиологическое ядро в интеллектуальных построениях). Ориу исходит из презумпции того, что «единственной целью государственного режима является свобода в ее гражданской и политической форме» [8 C.540]. Кроме того, автор полагает, что «государственный режим стремится к осуществлению гражданской свободы посредством свободы политической. Его идеалом является свобода, но проблема эта имеет двоякий характер, ибо индивид может жить только в политическом обществе, и вопрос свободы следует рассматривать как по отношению к индивиду, так и по отношению к политическому обществу. Государственный режим стремится к тому, чтобы осуществить некоторое политическое общество, само по себе свободное благодаря конституционной корпоративной организации, обеспечивающей, несмотря на разногласия, устойчивость этого общества, и внутри которой индивиды обладают гражданской свободой...» [8 C.540]. Подобные восприятие государственности восходит к нововременным конструкциям. Но главное следствие в подобных рассуждениях другое. Если следовать логике автора, то любой наличествующий государственный строй стремится к организации свободы в публичном пространстве, а называние власти «диктатурой» есть лишь методом управления. В этой связи, неудивительно, что Ориу описывает диктатуру как «средство борьбы против кризисов государственных режимов» [8 С.548]. То есть, по мнению автора, любой узурпатор - есть средство борьбы с проблемой, вызревшей в недрах государственной власти, а не его стремление к монополизации власти. Подобный подход представляется поверхностным. При такой методологии, как минимум, остаётся незамеченным разница между манифестацией, через которую диктатор легитимизирует себя, и политико-правовой реальностью. Даже 
если допустить, что диктатор мыслит себя как кризисный менеджер (или же «спаситель»- в более мессианской версии), то это не означает, что у других субъектов деятельности возникает обязанность идентифицировать его в качестве такового. Более того вытекает, что в орбите представлений Ориу, несогласные признать за диктатором роль борца с кризисами есть противники государственной стабильности. То есть, как минимум, такие рассуждения игнорируют понимание политического конкуренции и правовой «толерантности».

Возвращаясь к оценке двух «систематических доктрин», следует сказать следующее. У самого автора не наблюдается последовательность в использовании названий этих концепций. Условно их можно описать, как: (1) эгалитаристские и (2) антиэгалитаристские* доктрины. Политическое бытование чаще всего они находят в оппозиции революция - реакция. Следует отметить, что являюсь доктринами, они включают в себя целый комплекс идей на первый взгляд разной природы. Но автор выстраивает систему взаимосвязей между разрозненными элементами.

Целостность эгалитаристских характеристик по Ориу, влияющих на государственный механизм, выражается в следующем:

- примат революционного равенства над свободой [8 С.541];

- доминирование революционного равенства над социальной организацией [8 C.541].

Таким образом, пять сущностных наблюдений, которые выстраивает автор, можно свести к той сентенции, что эгалитаризм, действующий как принцип управления в государственном механизме, трансформирует (искажает) понимание свободы в публичном пространстве. Кроме того, сам термин «революционная свобода» противопоставляется «правовой свободе». При этом правовая свобода не всегда сопутствует антиэгалитаристским концепциям. Примечательно, что сам автор выдвигает понятие «революционного государства», которое позже свяжется с (квази) марксистскими доктринами. Таким образом, для обеспечения новой формы «свободы» само наличие не только традиционного государ- ственного аппарата, но и других социальных институтов, связанных с правовой свободой, является неуместным.

Противоположность эгалитаристскому космосу выступают концепция «культура - организующей силы» [8 C.544]. Центральная тенденция такой устремлённости - это не сохранение политической стабильности, а затормозить натиск и вытеснение новых «революционных» институтов прежними. Эта догма, по мнению, Ориу оформляется в четырёх положениях [8 C.544]. Примечательно, французский мыслитель исходит из того, что традиционное (неэгалитаристское) понимание свободы искажает его смысл. Дополнительно к этому, правовая свобода, обеспеченная силой социальных институтов, связывается автором с коллективизмом**. Такие выкладки позволяют сказать о недостаточной последовательности автора: смешение разнородных по природе явлений и подмена их понимания.

В свою очередь структура диктатуры у автора представлена в видовом разнообразии. Это наличие трёх форм: фактической, чрезвычайной и заранее предусмотренной [8 C.549]. Собственно, объединяет все три вида диктатуры факт расширения власти и её консолидация в лице одного лица [8 С.549]. Автор исходит из нового понимания свободы, что сказывается на характере теоретизирования о разделении властей. Так автор фиксирует, что «во время войны разделение властей должно быть только разделением функций, устанавливающим сотрудничество, с проявлением наибольшей компетенции всех участвующих в нем лиц» [8 С.551]. Подобное понимание принципа разделения властей можно назвать милитаристским. Он является не пост-макиавеллиевский, а скорее - антимакиавеллиевским. Если обратится к современным способам осмысления политических традиций республиканизма [9], то можно обнаружить несогласие с той системой интерпретаций, которая стала возникать в социальной наук на излёте XIX века. Феномен флорентийского республиканизма не был лишён компонента новаторства. В этой аспекте можно проводить параллель между понятием «революционной свободы» как элемента пост-

\footnotetext{
* Сам Ориу называет их течениями, которые могут быть описаны с помощью концепции «культура как организующая сила» (См.: Там же. С. 543 и др.).

** «Революционное государство склонялось в сторону индивидуалистического или почти анархического коммунизма, государство «культуры - организующей силы» - в сторону фельдфебельского коллективизма» (Там же.).
} 
модерна, наравне с с концепцией «республики», которая была продуктом Нового времени. Новаторство проявлялась в том, что «новый государь не является потенциальным законодателем и что законодатель - идеальный тип, расположенный на одном из полюсов категории новаторов, чьей разновидностью является новый государь ... он учреждает stato - ограниченную форму правления, отчасти легитимную, отчасти укорененную в обычаях и «вторичной природе», новых для данного народа.» [9 С.150-151]. Таким образом, нововременная государственность являлась в том числе правовым институтом, отвечающим на политический вопрос о легетимности власти. А рассуждения французских эгалитаристских мыслителей обходили этот вопрос как уже несуществующий. Вместе с тем он оставался неразрешённым. А концепции упразднения социальных институтов, которыми пропитаны теории власти, его радикальным образом обнуляли.

Кроме того, рассуждения эгалитаристов о природе власти и права, как уже было показано ранее, искажённо трактуют понимание дихотомии коллективизм-индивидуализм. Так отмечал современник Ориу, но очевидно находившийся в орбите других ценностных констант, Шац [11]: «Английский и французский либерализм, различные с самого начала, в XIX в. противопоставлены друг другу еще более четко, чем в XVIII столетии. Первый, ставший более гибким благодаря Стюарту Миллю, который лишь придал ему форму, подходящую к британскому характеру, занимает все большее место в национальной жизни, открыто принят в качестве доктрины сильной политической партией, ныне находящейся у власти и сумевшей добиться успехов в экономическом вопросе, смело поставленном и подвергнутом разумному обсуждению» [11 С.251]. Таким образом, можно сделать два важных теоретических следствия: теоретические антитезы против классического понимания «правовой свободы» воплотились не только в германской марксистской традиции, но и в параллельной течении: французском эгалитаризме. В широком смысле понимания этих течений можно найти единую природу, но история формирования, национальный политический контекст по-разному повлиял на государственный механизм.

Важно отметить другую социальную законо- мерность. Пафос эгалитаризма был направлен в том числе на то, чтобы обосновать возможности корректировки принципа разделения властей. Как выше уже было описано, диктатура имманентно преследует цель его упразднения. Но сам принцип разделения властей возможен лишь при оформившейся и устойчивой социальной структуре «зрелой» государственности. Например, как отмечается в современных работах американистов [2], на ранней форме зарождения публичной власти в колониях, нельзя выделить такую форму не только как разделение власти, но и более того, публичная власть. В контексте вышеописанной структуры общества, невозможно говорить о наличие эгалитаризма. Можно заключить, что появление перераспределительной системы институтов публичной власти, а равным образом - наличию доктрин, обосновывающих их существование, предшествует нарастание социальной сложности до состояния «зрелой государственности» с неизбежным её спутником - кризисом государственного механизма.

На современном этапе кризис государственного механизма связан, прежде всего, с процессом его формирования. В данном случае, речь идёт не о проблеме бюрократии или эффективности замеров государственного управления. Магун точно подмечает, что «демократия определяется не только социальными факторами, но и общей системной формой, в которой она образует политико- идеологический интерфейс. Эта форма - капитализм» [6 С.128]. Таким образом, капитализм выступает не формой выражения демократии, но его необходимым условием. Так что вопрос, «есть ли будущее у капитализма?» [10; 3] скрывает в себе и ответ о формах политического режима.

Изменения характера экономических отношений в конце XX - начале XXI века, расширение вовлеченности граждан в участие в политических процессах («рост неиституционализированного политического участия» [7]), изменение административных стандартов и создание новой сферы публичного права в пределах западных политий создаёт запрос на новые понятия. В социально-правовых и политических работах всё чаще нарастают такие определения, как: «постдемократия» [5]. 


\section{Библиографический список}

1. Антонов М.В. Теория государства и права: учебник и практикум для академического бакалавриата / М.В.Антонов. - М.: Издательство Юрайт, 2019. - 497 с.

2. Белькович Р. Ю. Кровь патриотов: введение в интеллектуальную историю американского радикализма. СПб.: Владимир Даль, 2020. - 384 с.

3. Есть ли будущее у капитализма? / пер. с англ. [А. Аполлонсокго и др.] под ред. Георгия Дерлугьяна. - М.: Изд-во Ин-та Гайдара, 2015. - 316 с.

4. Жакке Ж.-П. Конституционное право и политические институты: Учеб. пособ. / Пер. с франц. В. В. Маклакова. - М.: Юристъ, 2002. - 360 с.

5. Крауч К. Постдемократия [Текст] /пер. с англ. Н. В. Эдельмана. - М.: Изд. дом Гос. ун-та - Высшей школы экономики, 2010. - 192 с.

6. Магун А.В. Демократия, или Демон и Гегемон. - СПб.: Издательство Европейского университета в СанктПетербурге, 2015. - 160 с.

7. Манен Б. Принципы представительного правления / пер. с англ. Е. Рощина. - СПб.: Изд-во Европейского ун-та, 2008. - 322.

8. Ориу М. Основы публичного права: монография. - М.: ИНФРА-М, 2013. - 572 с.

9. Покок Д. Момент Макиавелли: Политическая мысль Флоренции и атлантическая республиканская традиция. - М.: Новое литературное обозрение, 2020. - 888 с.

10. Филд Дж. Есть ли будущее у капитализма? - М.: Ад Маргинем, 2019 г., 2019. - 144 с.

11. Шац А. Индивидуализм экономический и социальный. Истоки, эволюция, современные формы / пер. фр. В. П. Гайдамака, А. В. Матешук. - М.; Челябинск: Социум, 2021. - 706 с. 